\title{
EVALUATION OF WARFARIN ORAL USED BY INTERNATIONAL NORMALIZED RATIO VALUE AND DETERMINATION FREQUENCY TO CARDIOVASCULAR PATIENT AT HAJI ADAM MALIK GENERAL HOSPITAL, MEDAN, INDONESIA
}

\author{
DEWI PERTIWI ${ }^{1 *}$, EDY SUWARSO ${ }^{2}$, PARLINDUNGAN MANIK ${ }^{3,4}$ \\ ${ }^{1}$ Department of Pharmacology, Faculty of Pharmacy, University of Sumatera Utara, Medan, North Sumatera, Indonesia. ${ }^{2}$ Department of \\ Cardiovascular, Medical Faculty, University of Sumatera Utara, Medan, North Sumatera, Indonesia. ${ }^{3}$ Department of Cardiovascular, Haji \\ Adam Malik General Hospital, Medan, North Sumatera, Indonesia. Email: pertiwidewi92@yahoo.com
}

Received: 10 November 2017, Revised and Accepted: 13 January 2018

\section{ABSTRACT}

Objective: The objective of this research was to evaluate of warfarin oral used by value and determination frequency of international normalized ratio (INR).

Methods: The data of cardiovascular patients were collected from medical records in Haji Adam Malik General Hospital, Medan, North Sumatera, Indonesia, in 2016. This study evaluated the data by retrospective study design. The sample study was selected by Slovin method from the population of medical record of cardiovascular patients who received warfarin therapy. The sample of population was divided based on how many times the INR was measured. The groups are no measurement, once a year, unregularly schedule, thrice a year, and every month. The data were analyzed by analysis of variant to evaluated association of INR values and groups of patients.

Result: The total sample in this study was 90 patients based on Slovin formula. The percentage of patient who never gets INR checked was $18.89 \%$, once a year was $32.2 \%$, unregularly was $34.44 \%$, thrice a year was $8.89 \%$, and every month was $5.56 \%$. The value of INR in groups was $0.00 \pm 0.00$ in never checked group, once in year was $1.18 \pm 0.44$, unregularly was $1.79 \pm 1.00$, once time in 3 months was $2.04 \pm 0.73$, and every month was $2.42 \pm$ 0.91 . The groups of patients with never evaluation of INR value were significantly different with the other groups $(\mathrm{p} \leq 0.05)$.

Conclusion: The results obtained in this study indicated the majority patients group in case of warfarin oral used and evaluation of bleeding status were once checked in year and unregularly determination of INR value. The best condition, in this case, was the determination of INR value in every month caused the bleeding or coagulation status of patient can be evaluated.

Keywords: Warfarin, International normalized ratio, Cardiovascular, Hospital.

(c) 2018 The Authors. Published by Innovare Academic Sciences Pvt Ltd. This is an open access article under the CC BY license (http://creativecommons. org/licenses/by/4. 0/) DOI: http://dx.doi.org/10.22159/ajpcr.2018.v11i4.23600

\section{INTRODUCTION}

The bleeding is the common problem in cardiovascular disease. The two types of bleeding in cardiovascular are ischemic and hemorrhage. The bleeding event was caused by a disorder or manipulating (mechanic or pharmacologic) in the treatment of the disease [1]. The pharmacologic manipulation associated with clinically significant side effects from medicines and supplements $[2,3]$.

The bleeding is related to the anticoagulant grouped by minor and major bleeding. The minor bleeding such as in the nose, pharynx, urinary tract, soft tissue, and joint space. The major bleeding such as in cerebrovascular (intracranial) and gastrointestinal (40-60\%) systems that may occur in the retroperitoneal region and intraocular. Intracranial hemorrhage is a fatal hemorrhage associated with warfarin therapy. Although the incidence is estimated to range from $0.3 \%$ to $2 \%$, $60 \%$ of sufferers experience death from the incidence value [4].

Heparin is a parenteral anticoagulant that acts as indirect thrombin inhibitor and is extensively used for treatment and prophylaxis of several thromboembolic conditions in clinical practice. Heparin is a heterogeneous mixture of sulfated mucopolysaccharides whose biologic activity is dependent on the endogenous anticoagulant antithrombin. Commonly use oral anticoagulant is warfarin [5].

The $50 \%$ of the bleeding that occurs is major bleeding. The bleeding associated with warfarin causes morbidity due to transfusion and hospitalization. An average of 1 in 10 major hemorrhages causes death and 1 in 12 patients will experience bleeding after reuse of warfarin [6]. During the development of research on major bleeding related to warfarin, the mortality rate reached $9.5-13.4 \%[7,8]$. An examination of the international normalized ratio (INR) in patients receiving warfarin therapy is needed to monitor the chances of bleeding $[9,10]$.

Based on high mortality rate due to bleeding because of warfarin usage, evaluation of warfarin based on INR value and relation with bleeding number of patient needs to be evaluated. In this study, patients of cardiovascular disease who received warfarin were grouped by frequency of the determination of INR values.

\section{METHODS}

Ethical clearance

The study was approved by Health Research Ethical Committee, Medical Faculty of University of Sumatera Utara/Haji Adam Malik General Hospital with an ethical clearance number of 368/TGL/KEPK FK USU-RSUP HAM/2017.

\section{Study design}

The study design in this research was case-control study. The data were collected by retrospective method for evaluation of clinical condition and identify study participants based on their case status in medical record. This study was compared and analyzing statistical associations between exposure and outcomes [11]. 
Time and location

This study was conducted at Haji Adam Malik Hospital from May to September 2017, and the data used in study were taken from 2016s data.

\section{Population and sample}

The population was all of the cardiovascular patients' medical record in Haji Adam Malik Hospital, Medan, Indonesia. The sample was collected by simple random sampling method from the medical record in 2016 year period. The simple random sampling method used the Slovin formula for count the number of sample from all of the population. The Slovin formula is:

$\frac{\mathrm{n}=\mathrm{N}}{1+\mathrm{Ne}^{2}}$

$\mathrm{n}$ : The number of sample, N: The number of population, e: The number of deviation or error $(10 \%)$

The collected sample was grouped by the type of determination frequency of INR value; there are no measurements, once in year period, unregularly, thrice a year, and every month.

\section{Statistical analysis}

Statistical analysis was conducted using analysis of variant method to identify significantly different between all groups and conclude the relationship of determination frequency of INR value and warfarin used. In this study, the independent variable was determination frequency and dependent variable was INR value for the evaluation of coagulant or bleeding status in patients.

\section{RESULT}

\section{Characteristic of patients demography}

The number of patients by sex can be viewed in Table 1 .

Based on the data obtained, it is known that the number of male patients is greater than female patients. Warfarin usually prescribed because both male and female patients are equally at risk for blood coagulation.

The number of patients by age can be viewed in Table 2 .

Based on the data, patients with the most coagulation are patients over the age of 60 years, followed by patients between 50 and 60 years. The older the human age the ability of the organs of the body to work decreases. In this case, blood clotting factors with age also decrease in function so it is more susceptible to coagulation. Patients in this age range should be more supervised during warfarin prescribing because age is a risk factor for heart disease.

The INR value by the group of determination frequency can be viewed in Table 3.

Based on the data, it can be concluded that the INR checks performed every 1 month are the most appropriate frequency. From statistical data, checks every 3 months and 1 month can be evaluated, but for examination, every 3 months does not differ significantly with irregular examination, so the examination every 1 month is the best result. The 0.00 value in the never measured group is not the true value but indicates that the value is unknowable.

\section{DISCUSSION}

Based on medical record, the number of patients who do not regularly performs the INR (laboratory), one of which is due to patient disobedience to the therapy procedure. The patient's educational, economic, social, and psychological affects him immensely. Noncompliance increases mortality, morbidity, and hospitalization. Compliance is the patient's own responsibility to follow a medical therapy program. Compliance is a multidimensional phenomenon that interacts among many factors $[12,13]$.
Table 1: The number of patients by sex

\begin{tabular}{ll}
\hline Sex & n (\%) \\
\hline Male & $47(52.22)$ \\
Female & $43(47.78)$ \\
\hline
\end{tabular}

Table 2: The number of patients by age

\begin{tabular}{ll}
\hline Ages (years) & $\mathbf{n}(\%)$ \\
\hline $20-30$ & $7(7.78)$ \\
$31-40$ & $20(22.22)$ \\
$41-50$ & $15(16.67)$ \\
$51-60$ & $23(25.56)$ \\
$>60$ & $25(27.78)$ \\
\hline
\end{tabular}

Table 3: The INR value by group of determination frequency

\begin{tabular}{lll}
\hline No & Groups & INR values \\
\hline 1 & Never & $0.00 \pm 0.00$ \\
2 & Once in 1-year period & $1.18 \pm 0.44^{*}$ \\
3 & Unregularly & $1.79 \pm 1.00^{*}$ \\
4 & Once time in 3 months & $2.04 \pm 0.73^{*}$ \\
5 & Every month & $2.42 \pm 0.91^{*}$ \\
\hline
\end{tabular}

INR: International normalized ratio. *The significantly different to groups that have never been measured (group 1). $\mathrm{p}<0.05$

INR monitoring in patients with low thrombotic risk is done daily until INR 2-3 is reached if it is stable enough to examine $4-6$ weeks. While for patients with high thrombotic risk, an initial examination is done every 3 days until the INR value reaches 2 , then every week to INR $2-3$, if the INR has stabilized then it should be checked once every 4-6 weeks [14-16].

Evidence suggests that stroke prevention by warfarin is effective when the time in therapeutic range (TTR) is either $>70 \%$. TTR is the proportion of time when INR 2-3 is achieved compared to overall duration of warfarin consumption. Therefore, continuous dose regulatory efforts should be made to obtain target values of INR 2-3. The difficulty of using warfarin in Indonesia is the unavailability of the INR inspection facility in peripheral areas. In this regard, it should also be noted that genetic factors in Indonesian ethnicity are related to the sensitivity of individuals to warfarin [17].

\section{CONCLUSION}

The examination of INR values is an important factor in the evaluation of coagulation and bleeding events in the treatment of cardiovascular disease using anticoagulant therapy such as warfarin with periodic checks; health workers can monitor the use of drug doses to achieve a better quality of life for patients.

\section{CONFLICTS OF INTERESTS}

Declared none.

\section{AUTHORS CONTRIBUTION}

The first author has carried out the research. Second and third authors have provided study conception, the design of work and critical revision.

\section{REFERENCES}

1. Kaya B, Yildiz I, Baha RM, Zeytun NE, Yetisgen A. Diffuse alveolar hemorrhage associated with warfarin therapy. Case Rep Med 2015;350532:1-3.

2. Zeichner SB, Cavalcante M, Barkin JA. Suplement use and gastrointestinal bleeding. Asian J Pharm Clin Res 2014;7:194-201.

3. Suliburska J. Pharmacological treatment may impair mineral status in blood. Int J Blood Res Disord 2014;1:1-2. 
4. Kimble MA, Young LY, Alldredge BK, Corelli RL, Guglielmo BJ, Kradjan WA, editors. Applied Terapeutics: The Clinical Use Of Drugs. $9^{\text {th }}$ ed. New York: Lippincott Williams \& Wilkins; 2009.

5. Shanmugapriya S, Bhuvanseswari K, Rashmi K. A study on the effect of low molecular weigth on potasium homeostasis in patients administered heparin for thrombophrophylaxis in a tertiary care hospital. Int J Pharm Pharm Sci 2017;9:85-9.

6. Guerroujj M, Uppal CS, Alklabi A, Douketis JD. The clinical impact of bleeding during oral anticoagulant therapy: Assessment of morbidity, mortality and post-bleed anticoagulant management. J Thromb Thrombolysis 2011;31:419-23.

7. Panduranga P, Al-Mukhaini M, Al-Muslahi M, Haque MA, Shehab A. Management dilemmas in patients with mechanical heart valves and warfarin-induced major bleeding. World J Cardiol 2012;4:54-9.

8. Linkins LA, Choi PT, Douketis JD. Clinical impact of bleeding in patients taking oral anticoagulant therapy for venous thromboembolism: A meta-analysis. Ann Intern Med 2003;139:893-900.

9. Kasinathan G, Pairan S, Rowther S, Sulaiman S, Basimin SA, Norazema S, et al. Efficacy of point-of-care testing (POCT) in reducing total waiting time at warfarin clinic of a district hospital: A cohort study. Open Access Libr J 2016;3:1-7.
10. Mathew E, Chandrika C, Karanath PM, Srinavasa R. Aprospective observational study on prescribing trends and adverse drug reactions in stroke patients. Int J Pharm Pharm Sci 2017;9:25-30.

11. Thiese MS. Observational and interventional study design types; an overview. Biochem Med 2014;24:199-210.

12. Smeltzer SC, Bare BG. Buku Ajar Keperawatan Medikal Bedah Brunner dan Suddart. Jakarta: EGC; 2002.

13. Notoatmojo S. Metodologi Penelitian Kesehatan. Jakarta: Rineka Cipta; 2005.

14. Department of Health. Guideline for Warfarin Management in the Community. Queensland Government: Royal Flying Doctor Service; 2016.

15. Chedepudi PR, Mounika O, Chandrika G, Franklin A, Ramesh M, Vanitha $\mathrm{RN}$, et al. Impact of pharmacist led anticoagulation monitoring and patient education on oral anticoagulation therapy with Acenocouarol. Asian J Pharm Clin Res 2017;10:314-7.

16. Christopher A, Sweet M. Assessing anticoaguation safety and efficacy in antiphospholipid syndrome patients monitored by factor II activity assay. Asian J Pharm Clin Res 2017;10:398-401.

17. PERKI. Pedoman Tata LaksanaFibrilasi Atrium. $1^{\text {st }}$ ed. Jakarta: Centra Communications; 2015. 